\title{
NADPH-Diaphorase Positive Neurons in the Retina of Bufo marinus: Selective Staining of Bipolar and Amacrine Cells*
}

\author{
Charles STRAZNICKY and Robert GÁBRIEL** \\ Department of Anatomy and Histology, The Flinders University of South Australia School of Medicine, Adelaide, SA, Australia
}

Received January 12, 1991

Summary. Unfixed retinal tissues of adult Bufo marinus were reacted for NADPH-diaphorase histochemistry that resulted in selective staining of populations of bipolar and amacrine cells. The number of stained bipolar cells in the retina was estimated to be $233,600 \pm$ 38,900 (mean \pm S.D.). These cells were non-uniformly distributed across the retina with the highest density of 4,308 cells $/ \mathrm{mm}^{2}$ along the visual streak decreasing to lowest density of 1,378 cells $/ \mathrm{mm}^{2}$ at the dorsal and ventral poles of the retina. The stained bipolar cells represented a morphologically uniform population.

The number of labelled amacrine cells in the retina amounted to $3,116 \pm 405$ including 251 cells that were displaced into the ganglion cell layer. Labelled amacrine cells were also unevenly distributed; with no stained cells in the retinal centre from where the density increased steadily to $72 \mathrm{cells} / \mathrm{mm}^{2}$ in the retinal periphery. NADPH-diaphorase positive amacrine cells were classified on the basis of their dendritic arborization pattern into three morphological types: 1) narrow-field cells both at the periphery and the centre of the retina; 2) wide-field amacrine cells, and 3) amacrines with eccentric medium-sized dendritic field.

The results of this study provide evidence for the presence of NADPH-diaphorase containing neurons in the anuran retina. Furthermore, this is the first report on the selective staining of bipolar cells for NADPHdiaphorase in the vertebrate retina.

Nicotinamide adenine dinucleotide phosphate diaphorase (NADPHd)-containing neurons of the mammalian retina were first described in detail in rabbit by SAGAR (1985) and in rat, cat, rabbit and in some primates by SANDELL (1985). The presence of this enzyme in subpopulations of amacrine cells of the mammalian retina was confirmed later (in rat: Mitrofanis, 1989; in cat: WäSSLE et al., 1987). The function of this enzyme is unknown at present, but it is supposed to take part in transmitter-related bio- chemical processes (VINCENT, 1986).

In different parts of the central nervous system in one species or in identical locations in different mammalian species NADPHd activity has been found to be co-localized with several putative neurotransmitter/neuromodulator substances (VINCENT and JOHANSSON, 1983; VINCENT et al., 1983a, b; VINCENT, 1986; Mizukawa et al., 1989). In the rabbit retina, this enzyme is present in a subpopulation of $\gamma$-aminobutyric acid (GABA)-positive amacrine cells, although other potential coexistences cannot be excluded.

It is surprising to find that only limited information is available on NADPHd reactive cells in nonmammalian species, in particular, in the anuran retina. Indeed, the presence of NADPHd containing amacrine cells has so far been demonstrated only in two non-mammalian species, in Columba livia and in Rana esculenta (SATO, 1990). The retinal distribution, the dendritic morphology and the potential neurotransmitter/modulator content of NADPHd stained neurons remain to be elucidated in anuran species.

Recently we have reported the presence and retinal distribution of neuropeptide Y (NPY) (HISCOCK and STRAZNICKY, 1989a), substance P (HISCOCK and STRAZNICKY, 1989b) tyrosine hydroxylase (TH) (ZHU and STRAZNICKY, 1990a) and 5-hydroxytryptamine (5-HT) (ZHU and STRAZNICKY, 1990b) immunoreactive amacrine cells of the Bufo marinus retina. The aim of the present study was to morphologically characterise NADPHd positive neurons in this species utilising a modification of the original SAGAR (1986) technique developed for the anuran retina (GÁBRIEL, 1991). Using unfixed retinal tissues for the NADPHd reaction two cell types, bipolar cells and subpopulations of amacrine cells, were stained. In this study we describe the dendritic morphology of these cells and their retinal distribution.

\footnotetext{
*This work was supported by a National Health and Medical Research Council Grant to C. S.

**R.G.: On leave from the Department of Zoology, Attila József University, Szeged, Hungary.
} 


\section{MATERIALS AND METHODS}

Adult Bufo marinus were captured in the wild and obtained from a North Queensland supplier. Animals were kept in tanks containing wet vermiculine, fed twice weekly with chopped liver and were exposed to $12 \mathrm{~h}$ day and night cycles. Animals were anaesthetized with intraperitoneal injection of $1 \mathrm{ml} 5 \%$ MS 222 (tricaine methanesulphonate, Sandoz) then sacrificed by decapitation. The right and left eyes were excised, and the neural retina was carefully dissected in $0.1 \mathrm{M}$ phosphate buffer (PB) containing $300 \mathrm{mM}$ sucrose.

\section{Histochemistry}

Isolated unfixed neural retinae were incubated in the following mixture: $15 \mathrm{mM}$ malic acid, $1 \mathrm{mM}$ NADP, $0.5 \mathrm{mM}$ nitroblue tetrazolium (NBT) and $0.2 \%$ Triton $\mathrm{X} 100$ in $0.1 \mathrm{M} \mathrm{PB}$ (pH 7.6), the final volume being 20 $\mathrm{ml}$. The reaction time was $2-3 \mathrm{~h}$ at room temperature. The reacted retinae were rinsed in $0.1 \mathrm{M} \mathrm{PB}$ and fixed in $4 \%$ buffered paraformaldehyde at least for 12 h. Retinal tissues were then either flatmounted on $4 \%$ gelatinised slides by applying radial cuts, the ganglion cell layer lying uppermost, or rinsed overnight in $30 \%$ sucrose buffer, embedded in Tissue-Tek OCT and sectioned in a cryostat. The sections were air dried and mounted in Depex. For controls, either NBT or NADP were omitted from the incubating medium, which resulted in no staining. All the chemicals used in the above procedures were obtained from Sigma.

\section{Morphometric analysis}

Five well stained retinal wholemounts were selected for analysis. Cell counts were carried out by the systematic scanning of the preparations at $300 \times$ magnification in $500 \mu \mathrm{m}$ steps. Sample areas were 0.2 $\mathrm{mm}^{2}$. Retinal areas were obtained from the measurements of camera lucida drawings of retinal wholemounts with a HIPAD digitizer linked to a Northstar Horizon computer. Total cell numbers were estimated by multiplying the mean cell densities and the corresponding areas between the neighbouring isodensity lines, then added these values. The dendritic branching of NADPHd positive cells were drawn from an Olympus microscope with the aid of a drawing tube at $200 \times$ magnification. The sizes of dendritic fields were measured from the camera lucida drawings. The mean values and \pm S.D. were calculated.

\section{RESULTS}

Two cell populations were found to be stained selectively for NADPHd: bipolar and amacrine cells. Weak reactivity was also observed in the inner seg. ments of the photoreceptors and the somata of some of the neurons of the ganglion cell layer. Stained bipolar cells represented a relatively large population, in contrast to the much smaller numbers of amacrine cells.

\section{Bipolar cells}

The average number of bipolar cells was $233,600 \pm 38$, 900 (mean \pm S.D.) with an uneven distribution across the retina. Peak cell density was observed in the retinal centre $\left(4,308 / \mathrm{mm}^{2}\right)$ whence the density decreased towards the dorsal and ventral poles of the retina to $1,378 / \mathrm{mm}^{2}$. Isodensity points in one retinal wholemount were joined to obtain an isodensity map of bipolar cell distribution (Fig. 1a).

These cells revealed the classical morphology of bipolar cells; dendritic branching in the outer plexiform layer (OPL) with a prominent protrusion, the 'Landolt clubs' into the inner segments of photoreceptors and axonal processes in the inner plexiform layer (IPL). Focusing onto different depths of the same field of a retinal wholemount preparation, the morphology of these cells could be clearly demonstrated. The Landolt-clubs of the bipolar cells were most intensely stained among other processes (Fig. 2a). Dendritic branching, located in the OPL, formed a loosely arranged fibre layer (Fig. 2b). The somata of bipolar cells were regularly located in the middle of the inner nuclear layer (INL) (Fig. 2c). The axonal processes of these cells branched across the whole width of the IPL with preference to the scleral sublamina (Fig. 2d). The axonal processes in the IPL were generally oriented towards the ciliary margin of the retina (Fig. 1b). The axons of bipolar cells regularly branched into 3-5 terminals (see camera lucida drawings, Fig. 1c). At the retinal edges, the morphological characteristics of the bipolar cells changed somewhat. These cells had shorter dendritic processes in the OPL and more elaborate axonal branches in the IPL, as seen both in wholemounts (Fig. 2e) and in transverse sections (Fig. 2f).

\section{Amacrine cells}

These cells showed an opposite density gradient to bipolar cells; higher density in the peripheral retina and low to very low density in the central retina (Fig. 

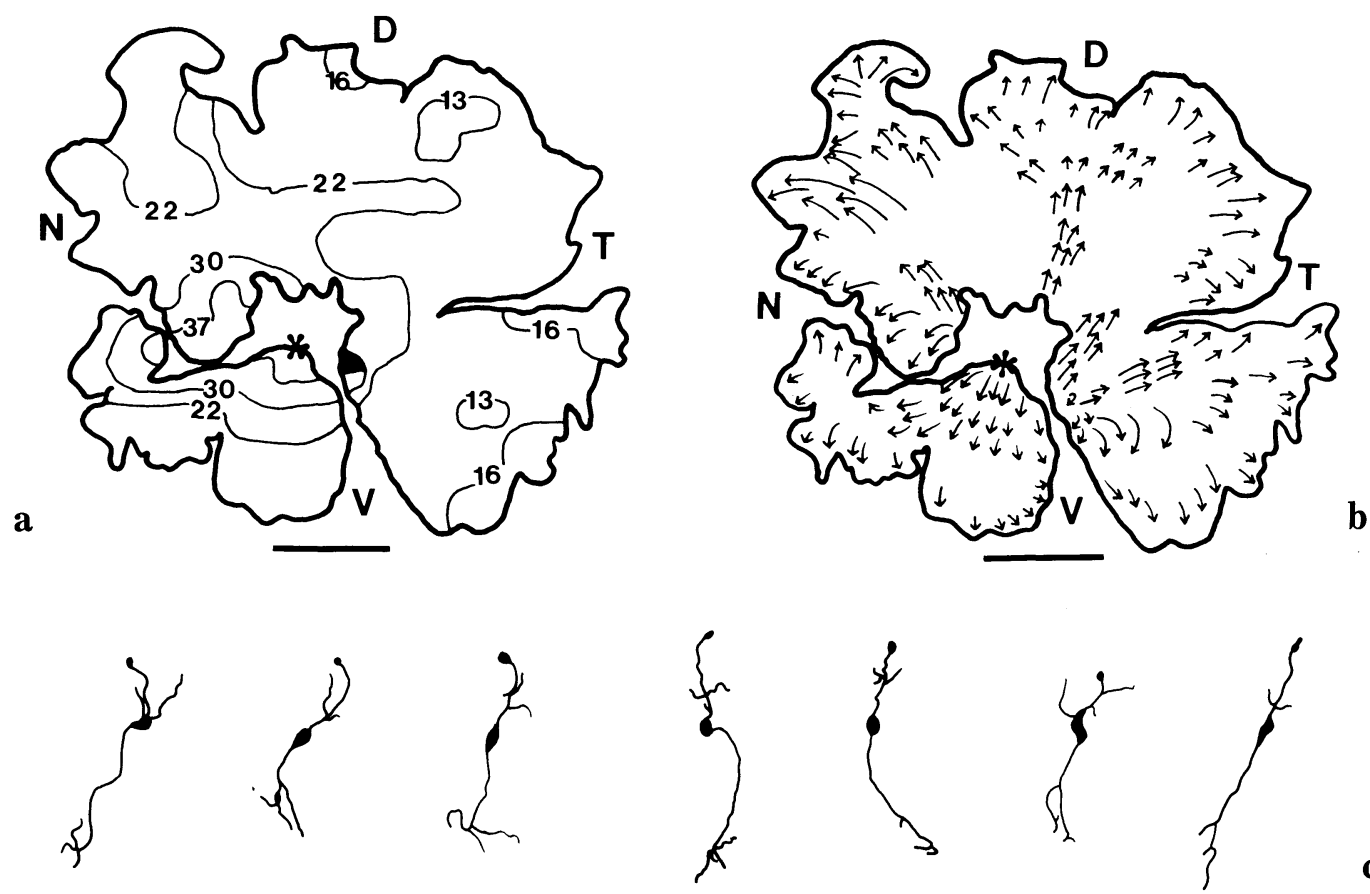

Fig. 1. Distribution and shape of NADPHd-positive bipolar cells. a. Isodensity map of the bipolars. The shaded area corresponds to the highest density of stained cells $\left(4,308 / \mathrm{mm}^{2}\right) . D$ dorsal, $V$ ventral, $T$ temporal, $N$ nasal directions. Asterisk: optic nerve head. Numbers are given in 100 cells $/ \mathrm{mm}^{2}$. Bar: $5 \mathrm{~mm}$. b. The arrows indicate the direction of axons of the NADPHd containing bipolar cells as seen from wholemounts. Note that axons are oriented towards the periphery of the retina. Asterisk: optic nerve head. Bar: $5 \mathrm{~mm}$. c. Camera lucida drawings of some stained bipolar cells from the retinal edges and the radial cuts.

3a). Average amacrine density was calculated to be 32 cells $/ \mathrm{mm}^{2}(\mathrm{n}=5)$, substantially less than those of the bipolar cells. The amacrine cells are easily recognisable amongst the stained bipolar cells, since their dendritic branching extends horizontally (Fig. 4a). Morphologically, 3 cell types could be distinguished by their dendritic branching patterns (see Fig. 3b): 1) narrow-field cells (Fig. 4b), located all over the retina, with 4-6 primary dendrites arising from the somata. The dendritic field sizes averaged 16 , $371 \pm 2,933 \mu \mathrm{m}^{2}(\mathrm{n}=20)$ of the centrally located and $13,308 \pm 4,690 \mu \mathrm{m}^{2}(\mathrm{n}=20)$ of the more peripherally located cells. 2) The second type showed an oval shaped dendritic tree with two main dendrites (Fig. 4c). The dendritic field size of $41,746 \pm 11,524 \mu \mathrm{m}^{2}(\mathrm{n}=$ 10 ), was the largest of all amacrine cell types. 3) The third amacrine cell type had a grossly eccentric dendritic tree formed by 2-3 main dendrites that branched approximately at right angles to each other as arose from the somata or from the only stem dendrite (Fig. 3d). The mean dendritic field sizes of these cells was $24,016 \pm 4427 \mu \mathrm{m}^{2}(\mathrm{n}=10)$. The exact ratio amongst the different peripheral amacrine cell types could not be determined with certainty because of the incomplete staining of many cells. In cross sections, most of the stained dendrites arborised in the scleral sublamina of the IPL (Fig. 4e). The total number of amacrine cell types within one retina was counted and estimated to be 3,116, including 251 displaced amacrines (Fig. 4f). Displaced amacrine cells appeared to have similar morphological characters to their orthotopic counterparts. The isodensity map of the stained amacrines was prepared from one retinal wholemount (Fig. 3a).

\section{DISCUSSION}

It has been reported in a previous paper (GÁBRIEL, 1991) that fixed anuran retinal tissue failed to have specific staining for NADPHd even after an extended period of incubation. Since the widely used technique 


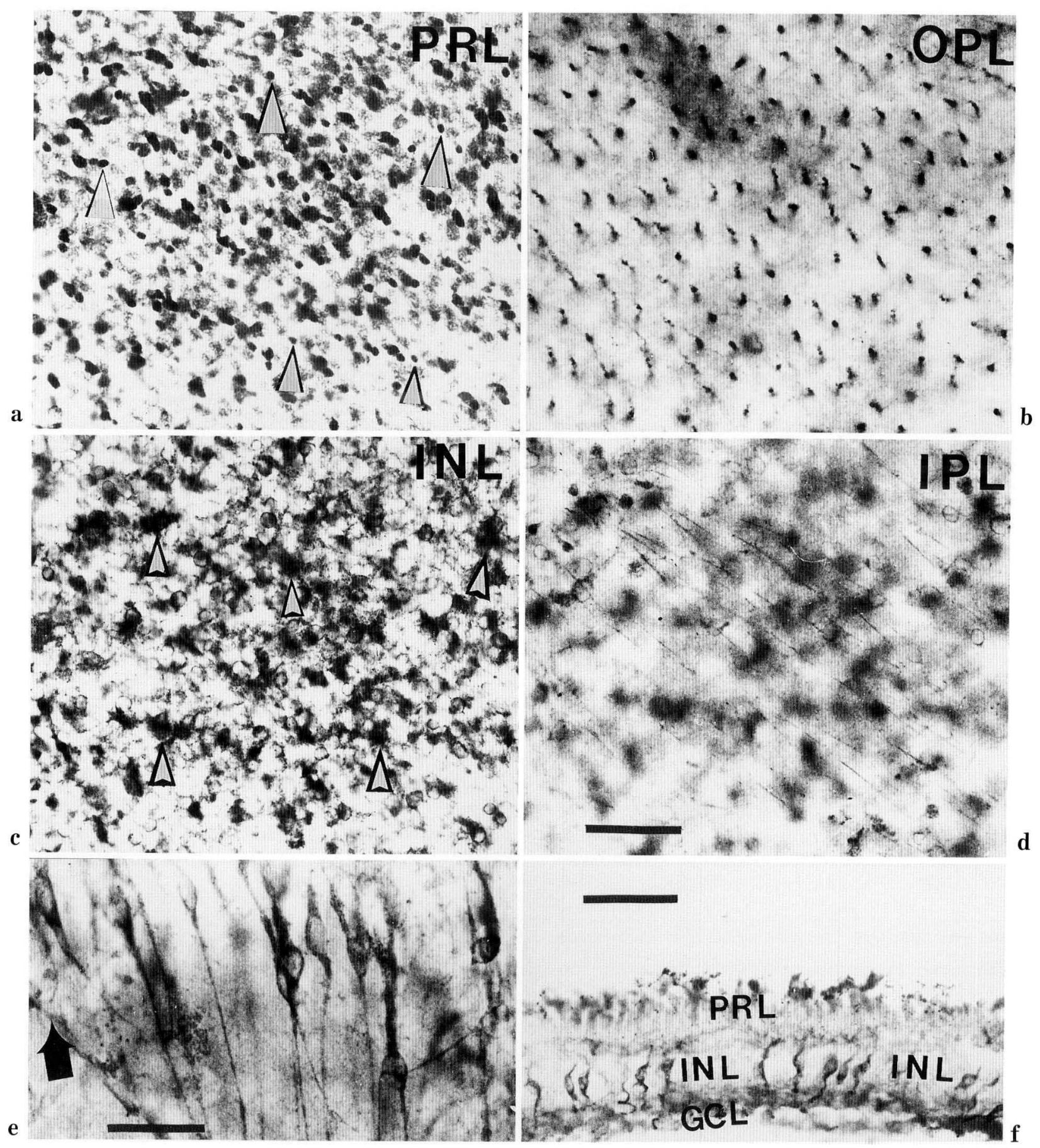

Fig. 2. Photomicrographs of NADPHd stained bipolar cells. a-d. Focal planes from the photoreceptor layer $(P R L)$, outer plexiform layer $(O P L)$, inner nuclear layer $(I N L)$ and to the inner plexiform layer $(I P L)$ of the central retina. Arrowheads point to the Landolt-clubs in a and to the perikarya in c. Bar in $\mathrm{d}=50 \mu \mathrm{m}$ and also applies to a-c. e. Bipolar cells at the edge of the retina. Note the shorter, thicker outer and the longer, thinner inner processes of the cells. Arrow indicates retinal periphery. Bar: $20 \mu \mathrm{m}$. f. Cross section from a stained wholemount. The characteristic shape of the bipolar cell perikarya in the inner nuclear layer (INL) is well recognisable. Note the slight nonspecific staining in the photoreceptor layer $(P R L)$ and at some sites of the ganglion cell layer $(G C L)$. Bar: $100 \mu \mathrm{m}$. 

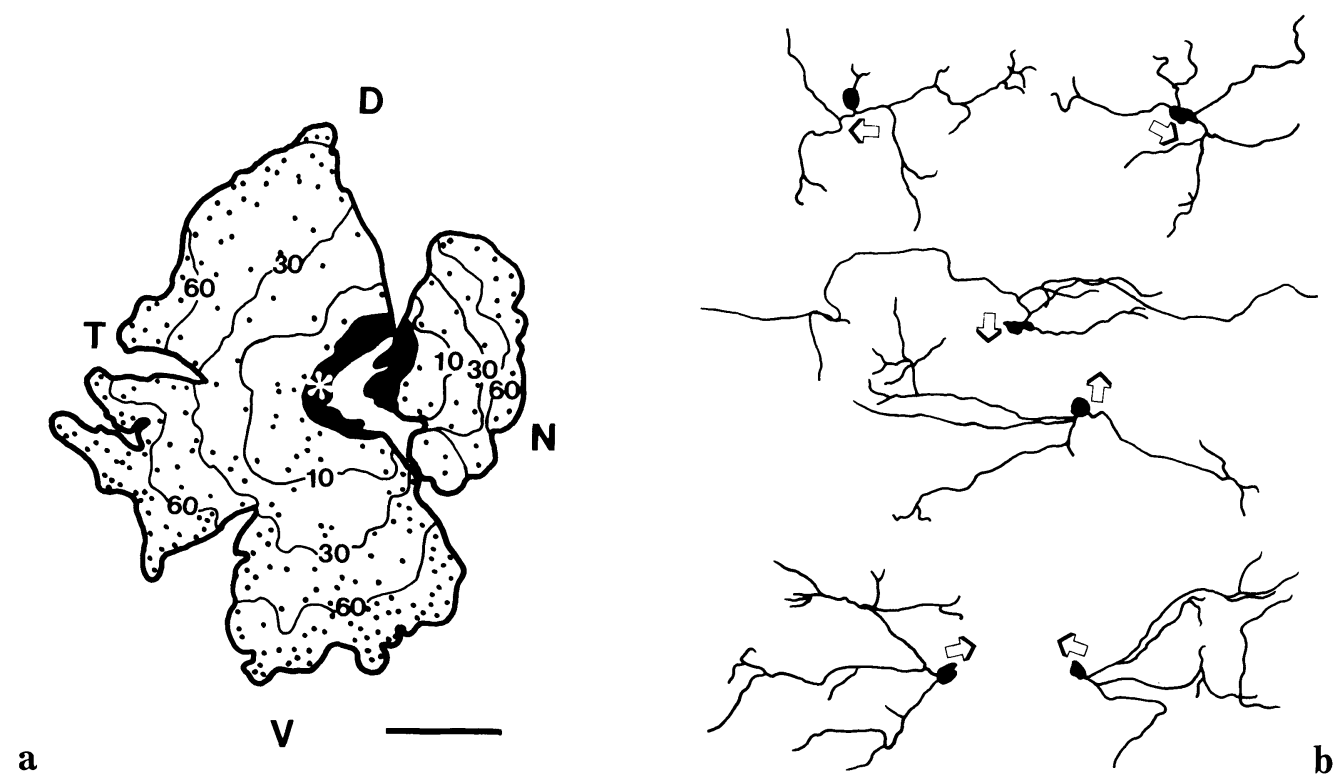

Fig. 3. Distribution and shape of NADPHd-containing amacrine cells. a. Isodensity map of the labelled amacrine cells (cells $/ \mathrm{mm}^{2}$ ). The shaded area contained no stained cells. The peak density at the periphery is 72 cells $/ \mathrm{mm}^{2}$. Dots indicate the positions of displaced cells. Asterisk: optic nerve head. Bar: $5 \mathrm{~mm}$. b. Camera lucida drawings of stained amacrine cell types. The upper pair of cells represents narrow-field, the middle pair wide-field whilest the bottom pair medium-field amacrines with eccentric dendritic tree. The small arrows at the cell bodies point towards the retinal centre.

of SAGAR (1986) successfully applied to fixed retinal tissues of various mammalian species was not suitable for the anuran retina, unfixed tissues were reacted for NADPHd.

Unfixed tissues for the demonstration of NADPHd activity in the mammalian retina has been used previously by KUWABARA and COGAN (1960), however, no comments were made on the morphology of the stained cell types. SAGAR (1986) has emphasised the lack of selective staining using unfixed rabbit retina. In contrast, we obtained consistent and selective staining of unfixed retinal tissues in the retina of Bufo marinus.

In all the mammalian and non-mammalian retinae examined so far, the reaction revealed only amacrine cells. Except for human (Provis and Mitrofanis, 1990) most of the other mammalian species showed at least two amacrine cell types, a larger and a smaller, (SANDELL, 1985; SAGAR, 1986; WÄSSLE et al., 1987). In non-mammalian species, both the frog and pigeon retinae have contained two (a strongly and a faintly stained) amacrine cell populations (SATO, 1990), however, the dendritic morphology of these cell types have not been elucidated.
Results presented in this study clearly showed that two major cell types, bipolar and amacrine cells, are selectively stained in the Bufo marinus retina. This is the first report that shows NADPHd positive bipolar cells and, therefore, interspecies comparisons cannot be made. The morphology of the NADPHd positive bipolar cells appear to be very similar across the retina, thus we regard them to be a homogenous population. Recently we have estimated the numbers of neurons in the INL of the retina in adult Bufo marinus to be about 10 million (ZHU et al., 1990). If $30 \%$ of these cells were considered as bipolars, the number of them may reach at least to 3 millions. The estimated number of 233,000 NADPHd positive bipolar cells, therefore, represents a sizable population but a small percentage of the total numbers of all bipolars in the Bufo marinus retina. The retinal distribution NADPHd positive bipolar cells follows the general cell density profile established for all layers of the adult retina (ZHANG and STRAZNICKY, 1991), in particular the centre to periphery density slope of $3.1: 1$ of the INL reported recently (ZHU et al., 1990).

In contrast to the retinal distribution of bipolar 

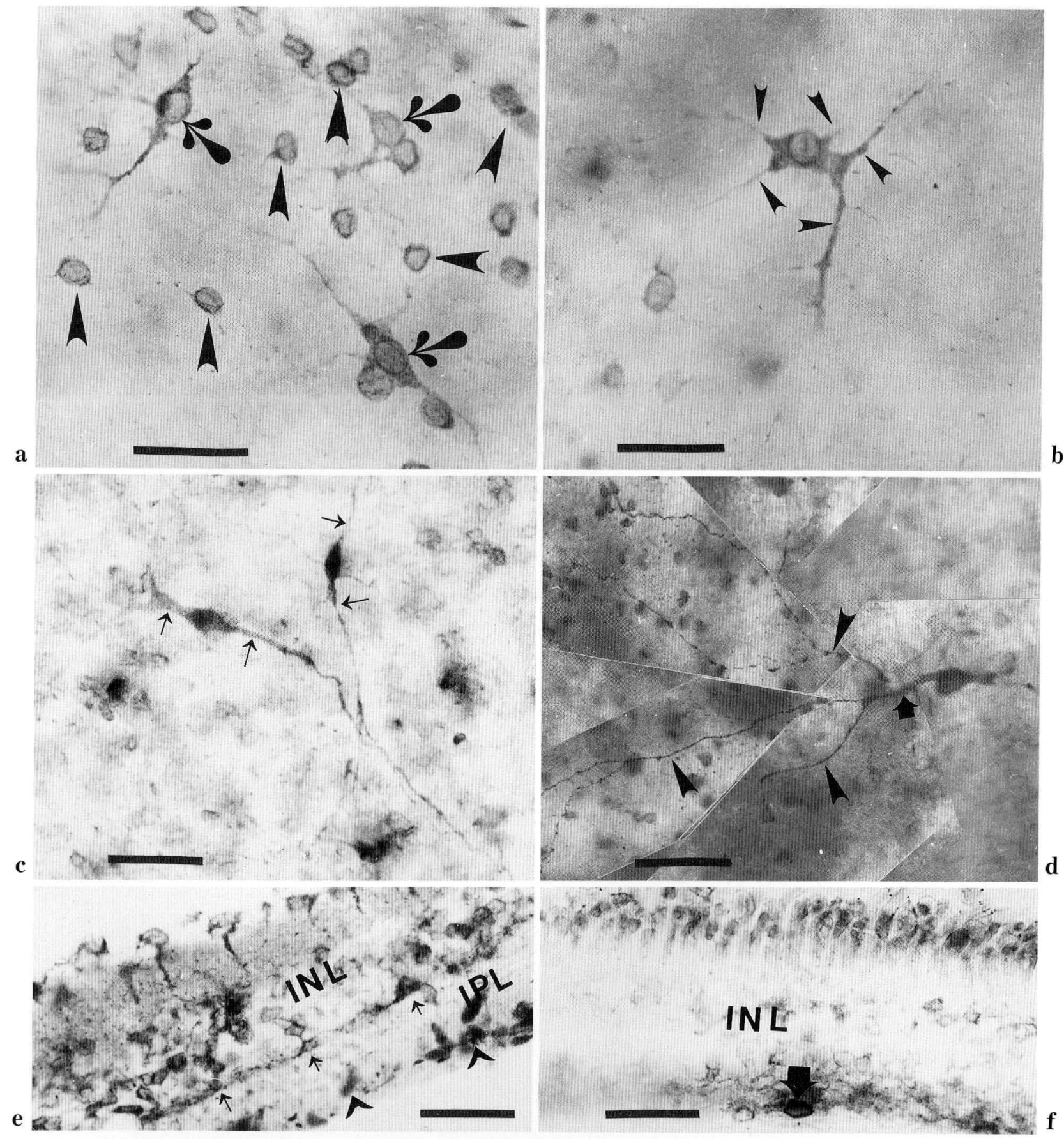

Fig. 4. Photomicrographs of NADPHd-labelled amacrine cells. a. Labelled amacrine cells (arrows) amongst the stained bipolars (arrowheads). Bar: $15 \mu \mathrm{m}$. b. Narrow-field amacrine cell. Arrowheads : stem dendrites. Bar: $15 \mu \mathrm{m}$. c. Wide-field amacrines with oval-shaped dendritic coverage. The two main dendrites of both cells (arrows) are clearly visible. Bar: $25 \mu \mathrm{m}$. d. Photomontage of an amacrine cell with eccentric dendritic tree. One main dendritic process emerges from the cell body (arrow) which splits into 3 main branches (arrowheads). Note the small process at the opposite end of the soma which ends within the inner nuclear layer. Bar: $25 \mu \mathrm{m}$. e. Cross section of a stained retinal wholemount. Amongst the several stained cells in the inner nuclear layer (INL) 3 amacrine cells can be clearly identified (arrows). Note that most of the stained processes are ramifying in the scleral sublamina of the inner plexiform layer (IPL). The arrowheads point at strongly stained cell somata of the ganglion cell layer $(G C L)$. Bar: $50 \mu \mathrm{m}$. f. Displaced amacrine cell (arrow) in the ganglion cell layer. INL inner nuclear layer. Bar: $50 \mu \mathrm{m}$. 
cells, the majority of NADPHd positive amacrine cells were located close to the ciliary margin. Similar differential distribution of NADPHd cells has been observed in the rat retina during development (MitrofAnis, 1989). The average amacrine density in the Bufo marinus retina $\left(32 / \mathrm{mm}^{2}\right)$ was found to be lower than that of the rat $\left(80 / \mathrm{mm}^{2}\right.$; Mitrofanis, $1989)$ and pigeon $\left(70 / \mathrm{mm}^{2}\right.$; SATO, 1990).

The reason for the predominantly peripheral distribution of NADPHd positive amacrine cells is not immediately apparent. Newly generated neurons have been shown to be added at the ciliary margin of the anuran retina throughout the life of the animal (STRAZNICKY and GAZE, 1971). It is likely that more cells are generated at the ciliary margin after metamorphosis than during larval life. This trend, combined with a possible loss of NADPHd content and/ or death of centrally located retinal neurons (JENKINS and STRAZNICKY, 1986) may account for the presence of increasing density gradient towards the retinal periphery, observed in adult animals. It appears at the same time, that bipolar cells probably retain the NADPHd activity throughout their life and that apparently more NADPHd positive cells are generated at the ciliary margin during development than after metamorphosis bringing about a higher cell density in the retinal centre and a lower density in the retinal periphery. This notion is supported by the observations in other anuran species suggesting that cell density differences across the retina may be due to differential cell addition at the ciliary margin both during development and in different parts of the retina in adult life (COLEMAN et al., 1984).

Considering the possible transmitter content, none of the well-characterised amacrine cell types of the Bufo retina (TH, 5-HT, SP and NPY) seems to correspond to NADPHd positive amacrine cells. The narrow-field amacrines show some similarities to the narrow-field 5-HT cells (ZHU and STRAZNICKY, 1990b). So far we have not been able to confirm possible co-localisation of NADPHd and 5-HT in this cell type. It is likely that neurons in the unfixed tissue release their 5-HT content and/or the formazan reaction and product masks the 5 - $\mathrm{HT}$ antigenic sites. GABA has been shown to colocalize with NADPHd in some of the rabbit amacrine cells (VANEY and YoUNG, 1988) and it may be a potential transmitter for some of the bipolar cells of the amphibian retina (YANG and YAZULLA, 1988). Further experiments are planned in this laboratory to unravel possible colocalization of transmitters with NADPHd in the retina of Bufo marinus.

The results of this study further strenghten the view, that the neurochemical organisation of the retina in different vertebrate species may be quite different even if they belong to the same taxonomical group (DowLING, 1987). Although NADPHd was shown to be a marker for two neuron populations in the retina of Bufo marinus, the role of this enzyme within the cellular metabolism or the role of NADPHd positive cells in the retinal microcircuitry require further elucidation.

Acknowledgements. The authors wish to thank to Drs. Jennifer HISCOCK, Judy WYE-DvoraK and Baosong ZHU for their valuable comments on the manuscript. Special thanks are due to Ms. Martha WILHELM for preparing the drawings.

\section{REFERENCES}

Coleman, L. A., S. A. Dunlop and L. D. Beazley: Patterns of cell division during visual streak formation in the frog, Limnodynastes dorsalis. J. Embryol. Exp. Morphol. 83: 119-135 (1984).

Dowling, J. E.: The retina. Belknap Press, CambridgeLondon, 1987.

GÁBRIEL, R.: A method for the demonstration of NADPHdiaphorase activity in anuran species using unfixed retinal wholemounts. Arch. Histol. Cytol. 54: 207-211 (1991).

Hiscock, J. and C. Straznicky: Neuropeptide Y-like immunoreactive amacrine cells in the retina of Bufo marinus. Brain Res. 494: 55-64 (1989a).

- Morphological characterization of substance P-like immunoreactive amacrine cells in the anuran retina. Vision Res. 29: 293-301 (1989b).

Jenkins, S. and C. Straznicky: Naturally occuring and induced ganglion cell death. Anat. Embryol. 174: 59-66 (1986).

Kuwabara, T. and D. G. Cogan: Tetrazolium studies on the retina III. Activity of metabolic intermediates and miscellanous substrates. J. Histochem. Cytochem. 8: 214-224 (1960).

Mitrofanis, J.: Development of NADPH-diaphorase cells in the rat's retina. Neurosci. Lett. 102: 165-172 (1989).

Mizukawa, K., S. R. Vincent, P. L. McGeer and E. G. MCGEER: Distribution of reduced-nicotineamide-adeninedinucleotide-phosphate diaphorase-positive cells and fibers in the cat central nervous system. J. Comp. Neurol. 279: 281-311 (1989).

Provis, J. M. and J. Mitrofanis: NADPH-diaphorase neurones of human retinae have a uniform topographical distribution. Visual Neurosci. 4: 619-624 (1990).

SAGAR, S. M.: NADPH-diaphorase histochemistry in the rabbit retina. Invest. Ophtalmol. Vis. Sci. 26(S): 261 (1985).

: NADPH-diaphorase histochemistry in the rabbit retina. Brain Res. 373: 153-158 (1986). 
SANDELL, J. H.: NADPH diaphorase cells in the mammalian inner retina. J. Comp. Neurol. 228: 466-472 (1985).

SATo, T.: NADPH-diaphorase positive amacrine cells in the retinae of the frog (Rana esculenta) and pigeon (Columbia livia). Arch. Histol. Cytol. 53: 63-69 (1990).

Straznicky, K. and R. M. Gaze: The growth of the retina in Xenopus laevis: an autoradiographic study. J. Embryol. Exp. Morphol. 26: 67-79 (1971).

VANEY, D. I. and H. M. Young: GABA-like immunoreactivity in NADPH-diaphorase amacrine cells of the rabbit retina. Brain Res. 474: 380-385 (1988).

VINCENT, S. R.: NADPH-diaphorase histochemistry and neurotransmitter coexistence. In: (ed. by) P. PANULA, H. PÄIVÄRINTA and S. SolCIA: Neurohistochemistry: modern methods and applications. Alan R. Liss, New York, 1986 (p. 325-396).

Vincent, S. R. and O. Johansson: Striatal neurons containing both somatostatin- and avian pancreatic polypeptide (APP)-like immunoreactivities and NADPHdiaphorase activity: a light- and electron microscopic study. J. Comp. Neurol. 217: 264-270 (1983).

Vincent, S. R., O. Johansson, T. HöKFELt, I. SKiRBoll, R. P. Elde, L. Terenius, J. Kimmel and M. Gold STEIN: NADPH-diaphorase: a selective histochemical marker for striatal neurons containing both somatostatinand avian pancreatic polypeptide (APP)-like immunoreactivities. J. Comp. Neurol. 217: 252-263 (1983a).

Vincent, S. R., K. SAtoh, D. M. Armstrong and H. C. FibigER: NADPH diaphorase: a selective histochemical marker of the pontine reticular formation. Neurosci. Lett. 43: 31-36 (1983b).

Wässle, H., M. H. ChUn and F. Müller: Amacrine cells in the ganglion cell layer of the cat retina. J. Comp. Neurol. 265: 391-408 (1987).
Zhang, Y. and C. StraZnicky: The morphology and distribution of photoreceptors in the retina of Bufo marinus. Anat. Embryol. 183: 97-104 (1991).

Zhu, B-S. and C. STRaZNiCKY : Dendritic morphology and retinal distribution of tyrosine hydroxylase immunoreactive amacrine cells in Bufo marinus. Anat. Embryol. 181: 365-371 (1990a).

- Morphology and distribution of serotonin-like immunoreactive amacrine cells in the retina of Bufo marinus. Visual Neurosci. 5: 371-378 (1990b).

ZhU, B-S., J. Hiscock and C. Straznicky: The changing distribution of neurons in the inner nuclear layer from metamorphosis to adult: a morphometric analysis of the anuran retina. Anat. Embryol. 181: 585-594 (1990).

YANG, C.-Y. and S. YAZULLA: Localization of putative GABAergic neurons in the larval tiger salamander retina by immunocytochemical and autoradiographic methods. J. Comp. Neurol. 277: 96-108 (1988).

Dr. Charles StrazNicky

Department of Anatomy and Histology

School of Medicine

The Flinders University of South Australia G.P.O. Box 2100

Adelaide, SA, 5001

Australia 